\title{
CHAPTER TWENTY FOUR
}

NEW PHILOLOGY - VARIANTS IN ADAM IN BALLINGSCHAP (1664)

\author{
Jan Bloemendal
}

\section{Adam in Ballingschap, its Genesis and First Readers}

When Vondel wrote his Adam in ballingschap (Adam Exiled) in 1664, its model had been published more than sixty years earlier and its author - who had been a good friend of Vondel's - had been dead for almost twenty years. It was in 1601 when a young Hugo Grotius (15831645) wrote and published his Adamus exul (Adam Exiled), on the theme of the first and foremost human tragedy, the loss of paradise. ${ }^{1}$ Or, as Grotius himself put it in the letter of dedication to Henry of Bourbon: 'the fall of Man from his pure and felicitous state into his present misery.'2

The subject of both tragedies is what John Milton called 'man's first disobedience / And the fruit of that forbidden tree / Whose mortal taste brought death into the world / And all our woe, with loss of Eden', told in Genesis 1-3 and by Flavius Josephus. ${ }^{3}$ And seemingly the object of both plays is 'to justify the ways of God to men', as Milton put it in his famous poem on the same subject, Paradise Lost $(1667,1,26) .{ }^{4}$ Vondel openly acknowledges his debt to Grotius's tragedy in the letter of dedication. He wrote a creative imitation, in which he made ample use of amplification. Whereas Grotius employed only one Sathan, for example, Vondel introduced three 'hellish' characters, and whereas Grotius presented only one angelus, Vondel replaced this angel with three of

\footnotetext{
${ }^{1}$ Grotius, Sacra in quibus Adamus exul tragoedia, The Hague (Albertus Henricus) 1601; Grotius, Adamus exul, ed. Meulenbroek.

${ }^{2}$ Grotius, Adamus exul, ed. Meulenbroek, pp. 24-25: 'Historia est prima quae in Sacris occurrit Literis et Catastrophen habet Hominis ex integro felicique statu in hanc miseriam lapsus'.

${ }^{3}$ Flavius Josephus, Antiquitates Judaicae (Jewish Antiquities) 1, 1, 4 [40-51].

${ }^{4}$ Cf. Tate, Milton's Paradise Lost and Vondel's Adam in ballingschap; Nyquist, 'Reading the Fall'.
} 
them. ${ }^{5} \mathrm{He}$ also changed the role of Eve, who in Grotius's play had been the evildoer par excellence, even before the Fall. Vondel's Eve is an ideal woman at the beginning, one that becomes a malefactrix only at the end. ${ }^{6}$ Furthermore, Vondel added a wedding party, which could have resulted from his wish to write a tragedy with a Sophoclean peripeteia, in contrast to his Senecan model. ${ }^{7}$

During his lifetime, only two editions were published, both in 1664 at the same printer's office. After Vondel's death, other editions appeared in the seventeenth and eighteenth centuries, separate ones in 1698 and 1736, and an edition as part of Alle de treurspelen (All the Tragedies) in $1720{ }^{8}$ Naturally it was included in all subsequent editions of the collected or complete works. It was not until 1910 that Adam in ballingschap was performed in Holland; ${ }^{9}$ Vondel himself never saw the play on stage.

Contrary to Grotius's play, Vondel's tragedy aroused some controversy. Three poems were promptly published in attack: one by Vondel's enemy Jacob Steendam, probably in 1664; one by Jan Pietersz. Beelthouwer (a good friend of Spinoza) in 1664 and 1671; and one by the otherwise unknown Meynarda Verboom, also in 1664. The latter took up the defence of Eve and was a gender reader even before the term existed. ${ }^{10}$

\section{Vondel and the Book}

In contrast to Shakespeare, who as a theatre professional was interested only in performances of his plays, Vondel engaged in the printing of his

${ }^{5}$ Vondel, Lucifer, Adam in Ballingschap, Noah, ed. Schenkeveld-van der Dussen, p. 301 .

${ }^{6}$ See also Vondel, Lucifer, Adam in Ballingschap, Noah, ed. Schenkeveld-van der Dussen, pp. 303-07.

7 Smit, Van Pascha tot Noah, 3, pp. 362-64; 372-74.

${ }^{8}$ Unger, Bibliographie, nos. 676, 677, 678 and 679, and 27a [2]; Schuytvlot, Catalogus, nos. 741-746.

9 A free (and spectacular) adaptation by Jan Frans Cammaert was rather popular in Flanders between 1756 and 1796; see Langvik-Johannessen, '1746: In de Brusselse Muntschouwburg wordt Charles Simon Favart directeur: Jan Frans Cammaert brengt de spektakelrijke première van Vondels Adam in ballingschap.'

${ }_{10}$ Unger, Bibliographie, nos. 878 (Steendam), 876 and 877 (Beelthouwer) and 879 (Verboom). The first two poems are published by Van Lennep and Unger, De werken, 1664-1667, pp. 323-25 and 327-38. Van Lennep (10, p. 458), gives an outline of the third. For the poem by Steendam, see also Vondelkroniek, 1 (1930), p. 82. The poem by Verboom was edited by Riet Schenkeveld in her Met en zonder lauwerkrans, pp. 304-12. See also her contribution in this volume, and Van Gemert, Women's Writing, pp. 48-49. 
dramas. This difference poses anew the question of the relation between printed text and performance. The book historian and Shakespeare scholar Kastan rightly states that both are dissimilar and discontinuous modes of production. ${ }^{11}$ The print conserves the text and fixes in time and space the word that performance releases as the very condition of its being. Viewed this way, performance makes, rather than enacts the text, and both of the expressions in common currency - 'page to stage' and 'stage to page' - are problematic. ${ }^{12}$ Thus printed texts of dramas have a life of their own. This chapter deals with the various (printed) texts of Vondel's dramas.

Remarkably, during his long lifetime Vondel himself had his dramas published by only a few printers. Vondel's firstling, Het Pascha (Passover), was published in 1612 at Adriaen Cornelison's bookshop in Schiedam, his second tragedy, Hierusalem verwoest (Jerusalem Destroyed), in 1620 by Dirck Pietersz. Pers in Amsterdam, and his De Amsteldamsche Hecuba and the highly controversial play Palamedes (1625-1626) by Jacob Aertz. Calom. Two or three plays were published by the famous cartographer and publisher Willem Blaeu: Sofompaneas and Gysbreght van Aemstel (1635 and 1637), and most probably Hippolytus (1628). When Blaeu died - perhaps to Vondel's relief, since the printer was a notoriously slow worker $-{ }^{13}$ Vondel went to Abraham de Wees. After his death in 1654 his widow continued her husband's office, as often happened in the sixteenth and seventeenth centuries. Vondel stuck with this publishing house until his last translations: Herkules in Trachin and Feniciaensche (Phoenician Women) of 1668. All plays were printed in quarto, except for Het Pascha of which the first edition was printed in octavo. We know almost nothing of the amount of copies that were printed. Only in the case of Lucifer is it recorded by Vondel's biographer Geeraardt Brandt that 1,000 copies of the first print were made. ${ }^{14}$ Furthermore, it is known that at the turn of the seventeenth and eighteenth centuries Vondel's plays were amply available. ${ }^{15}$

11 Kastan, Shakespeare and the Book, pp. 7-8.

12 The remark on the title page of the 1729 edition that it is '[n] ow for the first time printed word for word as it is being staged on the Amsterdam Theatre' (see infra) is telling. A different text had been performed than the one printed. Because of its controversial theme Palamedes was not performed at all.

13 Oey-de Vita, 'De edities van Gysbreght van Aemstel', pp. 94-95.

14 Brandt, Leven van Vondel, ed. Verwijs, p. 94 (ed. Leendertz, p. 45; ed. Van Oostrom and Schenkeveld-van der Dussen, p. 59); cf. Molkenboer, 'Vondels drukkers en uitgevers', p. 24.

15 The board of the guild of booksellers were asked for advice on a request from the Rotterdam publisher Pieter vande Veer. On 11 January 1700 they replied to the effect 
In 1660 twenty-three of Vondel's plays were reprinted by Kornelis de Bruyn in the handy octavo size. ${ }^{16}$ De Bruyn bound them together in two composite volumes, each work having its own pagination. Apparently in order to advance the interest of the 'Fellow Compatriots who Love Art and Poetry' (Konst- en Rijmlievende Landtslieden) for the 'Founding Father of Dutch Poetry' (Vader en Vinder der Nederlandtsche Poëzye) De Bruyn added his own preface and a laudatory poem by Jan Zoet.

This collection of Vondel's works was meant to be taken to the theatre as text booklets. Other, voluminous, editions of his collected works earned Vondel his place in the pantheon of Dutch poets. ${ }^{17}$ However, the terms 'Collected Works' or 'Complete Works' have to be qualified beforehand. The first collections of Vondel's works were composite sets of separate editions bound together by a private collector or by a publisher. In these instances no external editors were involved. The first real attempt to publish Vondel's Alle de wercken was made in 1793 when two Dordrecht and Bergen op Zoom publishers planned a project of fifteen or sixteen volumes. ${ }^{18}$ In the preface the editor, the retired minister Bernardus Bosch, expressed his conviction that every lover of Vondel could now afford to buy all his works. ${ }^{19}$ This was the beginning of a series of complete works edited by one (external and amateur) editor. ${ }^{20}$

It was only in 1855 , with the edition by the Dutch novelist Jacob van Lennep, that Vondel got his first genuinely Complete Works, in twelve

that that many copies of Vondel's works were available 'both in verse and in prose [...] in several copies and formats' (soo in rijm, als in prosa [...] in verscheijden stucken en formaten) printed by Dirk Boom, Jan de Wees, Gijsbert de Groot, And. van Damme, and W. and J. Lamveld and 'obtainable in large amounts from the same persons' (bij deselve nog in groote quantiteijt te bekomen), see Molkenboer, 'Vondels drukkers en uitgevers', pp. 27-28.

${ }_{16}$ Unger, Bibliographie, no. 24; cf. Molkenboer, 'Vondels drukkers en uitgevers', p. 27.

${ }_{17}$ Dongelmans, 'The Prestige of Complete Works'. Cf. Kastan, Shakespeare and the Book, p. 69, where he states that the Shakespeare folio edition tried to create him as an author; ibidem, p. 72, where he shows how the folio edition presented itself as literary, and especially ch. 3: 'From Contemporary to Classic: Textual Healing', pp. 79-110.

${ }_{18}$ Vondel, Alle de wercken, ed. Bosch. Unger, Bilbiographie, no. 37; Schuytvlot, Catalogus, no. 2.

19 See Dongelmans, 'The Prestige of Complete Works', p. 70.

20 In the 1820's the Amsterdam publisher and bookseller Marten Westerman published a new edition in 21 volumes (Unger, Bibliographie, no. 38). 
volumes. Van Lennep arranged the works in chronological order, in order to relate them to Vondel's life, and added annotations. ${ }^{21}$ The edition was rather expensive. An inexpensive edition was produced in two volumes made by the professor of Dutch literature Johannes van Vloten. ${ }^{22} \mathrm{He}$ modernised the spelling, annotated the text, and started to put Vondel on a pedestal in the preface by equating him with the painter Rembrandt and the admiral Michiel de Ruyter when he lauded him as the greatest Dutch poet. In 1867 this edition was reprinted with a new introduction that fitted in with the emancipation of the Roman Catholics in the (self-proclaimed Calvinist) Netherlands that had started in the meantime. Because of his conversion to Catholicism, Vondel became their icon and this edition served as a banner of their growing self-confidence. ${ }^{23}$

A monumental edition of Vondel's complete works (De werken: Volledige en geillustreerde tekstuitgave, or The Works: Complete and Illustrated Text Edition, 1927-1937) was the result of a collaboration between several specialists, edited in ten substantial volumes by the 'Wereldbibliotheek' (World Library), also known as the 'Maatschappij voor Goede en Goedkoope lectuur' (Society for the Distribution of Good and Inexpensive Literature), abridged as 'WB'. The edition was very expensive. Other, less expensive 'Complete Works' were published in 52 volumes by the Utrecht publishing house 'De Torentrans, edited by H.C. Diferee, and by the 'Hollandsch Uitgeversfonds', edited by Reinder Blijstra and Hettel Bruch, in twelve volumes. The Dutch poet and professor of Dutch literature Albert Verwey edited an equally inexpensive edition in one volume, which was reprinted, with a new introduction by Mieke Smits and Marijke Spies, for the Vondel commemoration year 1987. Vondel had been granted the prestige of several editions of his complete works.

But Vondel himself had been the 'editor' of his own works as well. He was critical about his works and kept correcting and changing them, either as a result of the changing circumstances, which allowed him to

${ }^{21}$ De werken van Vondel, ed. Van Lennep, see Unger, Bibiliographie, no. 39. The Leiden publisher Sijthoff bought the Van Lennep edition from Binger and asked the archivist Unger to revise and update it. It was published in thirty thin, very inexpensive volumes between 1888 and 1893 .

${ }^{22}$ Published by the Schiedam publisher Roelants; see Unger, Bibliographie, no. 41.

${ }^{23}$ Unger, Bibliographie, no. 43. See also Dongelmans, "The Prestige of Complete Works', p. 74. 
say more or less than before, or for stylistic reasons or reasons of delicacy. ${ }^{24}$ In the letter of dedication to Joseph in Dothan Vondel informs the readers about his conduct. Professor Van Baerle will help him to discern what is correct or wrong, 'and mending the faults, he will cause them to be corrected in the next print. ${ }^{25}$ Vondel cared about his work.

\section{Old and New Philology}

At first glance, it seems quite unproblematic to edit a play written by Vondel. Seldom do we have manuscripts, in many cases a set of contemporary editions that do not contain many different readings. Vondel's language is not always easy, ranging as it does from formal to colloquial, from the rhetorical genus sublime to the genus humile, but it can be explained in annotations. But the textual constitution itself does not seem overly complicated. It is no surprise, therefore, that in the vast body of scholarship on Vondel, the several editions attracted only occasional attention and, where they did so, this attention came from 'new bibliographers. ${ }^{26}$

Of course, there may be discussion surrounding the alteration to which the text has been subjected for the convenience of the readers, such as changes to spelling or punctuation, or translating it into modern Dutch. ${ }^{27}$ Such choices may be fundamental, but they mainly depend on the intended readership of the editions. ${ }^{28}$ Secondly, there is the intention of the editor, which is an important factor. What kind of edition does he or she want to produce? It may be a critical edition, an

${ }^{24}$ See Kalff, 'Vondels zelfcritiek'; Oey-de Vita, 'De edities van Gysbreght van Aemstel', pp. 82-87. On Vondel changing his works, see Brandt, Het leven van Vondel, ed. Verwijs, p. 124 (ed. Leendertz, p. 61; ed. Van Oostrom and Schenkeveld-van der Dussen, pp. 77-78). Several reasons are given by Kalff in 'Vondels zelfcritiek'.

25 ' $[\ldots]$ en de misslagen beterende, oirzaeck geven, die in den naesten druck te verbeteren', WB, 4, p. 76 .

${ }^{26}$ See (for example) Hellinga, Copy and Print; Gerritsen, 'De eerste druk van de Palamedes'; idem, 'Vondel and the New Bibliography'; Oey-de Vita, 'De edities van Gysbreght van Aemstel'. All authors mentioned draw attention to the material form and history of the book, which is the object of new or analytical bibliography. Analytical bibliography can be divided into descriptive (or physical) and historical bibliography. The former takes as its point of departure the description of the book, the latter the context in which a book is produced, i.e. is printed, published and distributed.

${ }^{27}$ Korsten, 'Twee nieuwe Vondels, of te oude?'. On literary criticism as preserver of heritage, see also Van Vaeck, 'Omgaan met "dichters van cierlijcke netheit".

${ }^{28}$ See Sneller's review of Schenkeveld's edition of Lucifer, Adam in ballingschap, and Noah, and Korsten 'Twee nieuwe Vondels, of te oude?'. 
annotated edition, a genetic edition, a reading text, or a facsimile edition, each with their own needs in terms of textual constitution and presentation, as well as in terms of commentary, each intended for a different readership. ${ }^{29}$ But in all cases, the editor is steering the interpretation of the reader by his or her choices with regard to the text, the annotations and the way in which those annotations are presented.

The issues on which there can be a more or less thorough debate seem to be the interpretation of some lines, scenes or the play as a whole, and the kinds of annotation the text requires. ${ }^{30}$ This commentary may differ, dependent on the type of edition produced and on the basic assumptions of the editor.

The Amsterdam 'neophilologist' Wytze Hellinga stated fundamentally that an editor should 'preserve texts and prepare their revival by research and information, and a commentator should enable the readers to understand the 'supply of facts' as it functioned in the days of the texts themselves, so that the distance between the old text and the modern reader would disappear. ${ }^{31}$ According to others, whose opinion differs slightly, the task of the commentator is to provide the modern reader with as much information as the ideal contemporary reader would have had. ${ }^{32}$ And a third stance - now scarcely applicable - is to reveal 'the author's intention'.

Before writing the commentary an editor has to establish 'the' or at least 'a' text. ${ }^{33}$ Modern editors of Vondel's plays often base themselves on the WB edition produced in the 1920s and the 1930s. ${ }^{34}$ And that they do so is quite understandable, as this has been the standard edition since its publication. The WB editors chose the first editions as their starting point. At any rate, they attempted to publish an ideal

\footnotetext{
${ }^{29}$ Mathijsen, Naar de letter. Within the Dutch and German context, the 'historicocritical edition' and the 'study edition' are also discerned.

${ }^{30}$ These questions have been raised by Frans-Willem Korsten ('Twee nieuwe Vondels, of te oude?') and by Agnes Sneller in their reviews of the editions by Konst and Schenkeveld-van der Dussen.

${ }^{31}$ Hellinga, 'De commentaar', pp. 110 ('teksten te bewaren en de herleving ervan door onderzoek en voorlichting voor te bereiden'), and 117. Cf. Spies, 'Vondel in veelvoud', p. [9]/246.

32 See Matthijsen, Naar de letter, pp. 333-51. Spies.

${ }^{33}$ The exemplary edition of two of Vondel's poems on shipping made by Marijke

${ }^{34}$ Vondel, Gysbreght, ed. Smits-Veldt, idem, Jeptha etc., ed. Konst, pp. 304-07; idem, Lucifer etc., ed. Schenkeveld-van der Dussen, pp. 331-33 (here, p. 331, unfortunately for Adam in ballingschap WB, 9 is referred to, instead of WB, 10).
} 
text', as close as one can get to the 'author's intention. ${ }^{35}$ In the case of Adam in ballingschap, too, the editor Molkenboer, has chosen to take one of the two editions from 1664 as his basis. ${ }^{36}$ In a way, in doing so he dovetailed with positivistic classical textual criticism in the paradigm of Lachman. ${ }^{37}$ This 'Lachmannian method' also tried to establish an Urtext, as close to the author's ideal text as possible. For early modern and modern texts, the ultima manus ('Ausgabe letzter Hand') is often taken as the starting point of the edition, depending on the type of edition to which is aspired. This reveals a fundamental difference between classical and modern philology: classical philology deals with the transmission of the text, its modern counterpart mainly with its genesis. Of course, this difference has to do with material differences; there are no autographs of classical authors, while in some texts that are the object of modern philology several (autograph) phases of the same text are extant.

In 1989 the French medieval scholar Bernard Cerquiglini upset medieval scholarship with his book Léloge de la variante (translated as In Praise of the Variant)..$^{38} \mathrm{He}$ pleaded for a theoretical reappraisal of the variants in medieval manuscripts, with an appeal to the reception of the texts, distinguishing between manuscripts and printed books. Medieval readers did not consume an ideal text, but the text as it was before their eyes. They did not have a concept of a definitively complete text, but a text was considered 'open', and each reader or copyist, even the author himself, was expected to adapt the text to perpetually new circumstances and (social) contexts in which the text was copied. ${ }^{39}$ Therefore, he states, the task of an editor should not - or, I add, not only - be the constitution of an ideal text, but the presentation of a text with its variants in the several manuscripts. Cerquiglini, therefore, focussed on two main points: firstly, that variance is an essential feature of the medieval text, and secondly, that modern scholars have mistreated the medieval text by editing the variance out of it. His approach was one of the foundations of 'New Philology', as it was labelled by

\footnotetext{
${ }^{35}$ See Mathijsen, Naar de letter, pp. 21, 122, etc.

${ }^{36}$ Unger, Bibliographie, no. 676; Schuytvlot, Catalogus, no. 741.

37 See Mathijsen, Naar de letter, pp. 20-22; West, Textual criticism.

${ }^{38}$ Cerquiglini, Éloge de la variante; idem, In Praise of the Variant. For this survey I was helped by the convenient summary presented by Werner Gelderblom in an unpublished paper 'Erasmus en de nieuwe filologie'; he is also to provide an example of the application of New Philology to Neo-Latin texts in his anticipated edition of the poems by Janus Secundus.

${ }_{39}$ Provocatively he stated: 'Now, medieval writing does not produce variants; it is variance', Cerquiglini In Praise of the Variant, pp. 77-78 (see also idem, Éloge de la variante, p. 111).
} 
Stephen Nichols in a thematic issue of Speculum bearing that name. Since the term encountered some opposition from the 'old' philologists, Nichols proposed to change it into 'material philology'. ${ }^{40}$

It seems that the label New Philology is mainly ideological, while 'material philology' (note the difference in capitals and minuscules) has a mainly practical orientation. In any case, ideologically, 'New' and 'Old' Philology differ at several levels and in several respects. Whereas 'Old' is concerned with the independent authority of a text with its verbal essence, 'New' deals with the text as it is in its material form; whereas the aim of 'Old' is to reconstruct the text (if necessary) by intervention, apart from its original context, 'New' sets out to simulate the material forms of the text in comparison and contextualize it; whereas 'Old' has as its hero the author, for 'New' the scribe or the printer holds more importance; finally, 'Old' loves unity, 'New' is fond of variance. ${ }^{41}$

At first sight, such explicit attention to variance does not apply to early modern texts. We do not have many variant texts caused by misreadings, or the interpolation of glosses. And more fundamentally, the invention of movable type made it possible to make texts in hundreds of copies without variance. ${ }^{42}$ But even then variants appear. The starting point differs, however; variants are now often a result of the genesis of the text - in the author's mind or on the printer's press - or of its reception. ${ }^{43}$ On the other hand, the variants were not only caused by the reception of Vondel's works, but they steered it as well. For this reason the variants of Vondel's texts should retain their significance. As for the editions that Vondel supervised himself, this helps to assess the relationship between the printer and the author; as for the other editions, it may shed some light on the ways in which the plays were received.

There are some fundamental assumptions underlying these considerations: the need for relativism in the conception of the text; the conviction of a 'variability over time and space of any given work itself'; the idea of the dynamics of the text itself with is own 'material history', with its 'vast and largely uncharted alterations imposed by that history and by the mediation of generation upon generation of printers, editors, publishers', i.e. the conviction that there is no such thing as 'the'

\footnotetext{
${ }^{40}$ Nichols, 'Introduction'; idem, 'Why Material Philology?.

${ }^{41}$ See also http://magyar-irodalom.elte.hu/colloquia/000601/cerq.htm.

42 See, for example, Eisenstein, The Printing Press as an Agent of Change and Martin, The History and Power of Writing.

${ }^{43}$ In the Middle Ages it was the scribes who steered or even determined the reception.
} 
text. ${ }^{44}$ But nowadays scholarship is aware of the 'fluidity' of texts, especially theatrical texts. This certainly holds true in view of the paradigm shifts literary scholarship has witnessed, from the nineteenth-century 'evolutionary' and 'progressive' model (the author and his work were considered to develop and improve over time), through the 'monolithic' model (the literary text conceptualised as monolithic, invulnerable, existing in its extratemporal reality) to the postmodern, rather deconstructionist model of the text as a 'network' or 'sphere of influence. ${ }^{45}$ This opens the door to a more materialistic view of the text with increased interest in the several textual carriers, away from a Platonic or Neoplatonic idealist view of the search for the 'ideal' or 'best' text. ${ }^{46}$

With regard to the relationship between text and performance, analytical bibliography applies directly to the printed editions, but indirectly its results may shed some light on the performance tradition. Some editions reflected and steered the staging of the plays - leaving out the chorus lines, for instance, or adding tableaux vivants. Thus the editions influenced staging, and vice versa: performances had their impact on the editions.

\section{New Opportunities in Editing Vondel's Texts}

The question, then, is what implications such considerations could have for the philology of Vondel's texts. First of all, an editor should list the several editions and their sequel and relationships. There he can make use of analytical bibliography, analysing the typographical material, the paper used, and the bindings. ${ }^{47}$ Even in establishing the prints, problems may arise. In the same year, two editions of Adam in ballingschap appeared, slightly differing from each other. Which one was first? It can also be a serious problem to determine the order of the editions, as has been shown in the case of Palamedes. ${ }^{48}$ The edition dated 1626 must have been printed before the editions that have the year 1625 on their title page. Vondel altered the play considerably in $1652 .{ }^{49}$

\footnotetext{
${ }^{44}$ See Marcus, Unediting the Renaissance, p. 1.

${ }_{45}$ Marcus, Unediting the Renaissance, pp. 17-25; one could also speak of multiple factors; cf. Roland Barthes' famous essay 'From Work to Text'.

${ }^{46}$ Cf. Marcus, Unediting the Renaissance, pp. 29-30.

47 See, e.g., Hellinga, Copy and Print; Gerritsen, 'Vondel and the New Bibliography'.

${ }^{48}$ Gerritsen, 'De eerste druk van de Palamedes'.

${ }^{49}$ In his edition Jacob van Lennep printed the variants alongside the text. After in 1650 there were no stadholders in Holland anymore, more editions appeared
} 
The editor of a scholarly edition should take the changes into account, but anyone publishing a reading text should make a choice between the first edition and the ultima manus. As early as the seventeenth century it was necessary to annotate the edition. Geeraardt Brandt did so, and his remarks were published in 1705 as Aanteekeningen op J. van Vondels Palamedes in the 'Amersfoort edition' of Vondel's tragedy. ${ }^{50}$

The editor of Vondel's plays should take all these aspects into account before editing them. He or she should consider the specific circumstances of every play: its editions, several versions, proofs, and the annotations of Vondel and others. And the editor must always be aware of Vondel's attitude towards his works; he involved himself in the printing process and kept altering his texts. ${ }^{51}$ Here, some telling examples of problems the editor may encounter will be discussed: several differing versions of the text can exist, as in the case of Gysbreght van Aemstel; he may have to deal with the printer's proofs corrected by the author; remarks by Vondel on a performance may have been preserved, leading to a new text, as in Gebroeders (Brothers); or different prints that look alike may have been produced in the same year, such as the two first prints of Adam in ballingschap.

\section{Several Versions - Gysbreght van Aemstel}

Gysbreght is notorious for the history of its printings. ${ }^{52}$ There are two different editions from 1637 and 1638 . Vondel altered the text under the influence of the Amsterdam ministers' critique. The title page therefore states that it was 'corrected and enlarged by himself' (door

(see Unger, Bibliographie, pp. 38-39), and Vondel may have felt free to publish his pamphlet again. Kalff, 'Vondels zelfcritiek', and Walch, De varianten van Vondel's Palamedes - both influenced by the romantic Dutch 'Beweging van Tachtig', which focused on style and expression of emotions - assumed that the changes were mainly the result of linguistic and stylistic motives.

${ }^{50}$ See Kemperink, 'Een bijzonder exemplaar van Vondels Palamedes'. Unger, Bibliographie, pp. 5-6, assumed Rotterdam as the place of print, on the basis of typography and iconography. The annotations of Brandt were edited by Unger, 'Vondeliana IV: Palamedes', pp. 59-67. There is another edition of Palamedes, reputedly printed in Amersfoort by P. Brakman, containing a biting poem on William II, who attacked Amsterdam in 1650, on the occasion of his death. The poem never made it to the WB edition. See the contribution by Gaakeer in this volume, and Witsen Geysbeek, 'Vondel', pp. 80-82.

${ }^{51}$ Oey-de Vita, 'De edities van Gysbreght van Aemstel', p. 83.

${ }^{52}$ See Markus, 'De Gysbreght bestaat niet'; Oey-de Vita, 'De edities van Gysbreght van Aemstel'. 
hem zelf verbetert en vermeert). He also changed the term of address for Hugo Grotius in the letter of dedication. ${ }^{53}$ In 1659 the widow of Abraham de Wees published a version that Vondel had altered thoroughly..$^{54}$ After his conversion to Roman Catholicism, Vondel could no longer tolerate terms such as 'fate' (noodlot) anymore, and he changed them into expressions such as 'God's Providence' (Gods schickinge) or 'misfortune' (ongeval). He also left out the mute characters, perhaps to leave out a scene in which nuns were slaughtered in their monastery as something too blasphemous to show or tell. ${ }^{55}$ Another telling detail is the change of the address for Grotius from 'Your Excellency' (Exc[ellentie]) into 'Your Honour' (Edele). In the very sentence in which he dedicated the play to Grotius, he even left out 'Excellentie' without any substitution. ${ }^{56}$ Furthermore, Vondel added four lines to the monologue of Raphael, after 1. 1864, referring to Roman-Catholic faith:

If for you the demolishment of religiousness is too hard,

Stick firmly to the old faith and God's altar,

In the footsteps of the older ones who led the way courageously.

Thus one rushes to God immediately, through all stars. ${ }^{57}$

In 1720 Johannes Oosterwyk bought all copies left in the bookshop of Abraham de Wees and made his own quarto edition, in which for Gysbreght he followed the version of 1659 . This edition must be the ultima manus, so it is striking that WB and the last Gysbreght editor Smits-Veldt made their edition on the basis of the 1637 publication without giving an account of their choice.

Gysbreght van Aemstel was also printed in octavo, by Pieter vande Veer mentioned above. ${ }^{58}$ Most of his editions were made in the 1660 's, but according to Markus, Gysbreght was published in $1700 .{ }^{59}$

${ }^{53}$ A discussion of the variants can be found in Albach, Driehonderd jaar Gysbreght van Aemstel.

${ }^{54}$ The situation is highly complex; of this print three copies are extant, all are differing from each other. One of the three (UBA Vdl 8 C 12) must stem from 1699; see Markus, 'De Gysbreght van Aemstel bestaat niet'.

${ }_{55}$ A list of the changes can be found in WB, 3, pp. 927-31.

${ }_{56} \mathrm{He}$ was able to do so as Grotius had died in 1645.

${ }_{57}$ 'Valt u 't verwoesten der godtsdienstigheit te lastigh, / Volhardt by 't out geloof en Godts altaer standvastigh, / Op 't spoor der ouderen, u moedigh voorgetreên. / Zoo draeft men recht naer Godt, door alle starren heen.'

${ }^{58}$ Markus, ' $D e$ Gysbreght bestaat niet'. Pieter vande Veer could be a fictitious name; see Gerritsen's introduction to Schuytvlot, Catalogus, p. xxiii. See also p. 491, n. 15.

${ }_{59}$ Markus, 'De Gysbreght bestaat niet'. 
Three copies are extant, that also differ from each other. ${ }^{60}$ They can be traced back to the 1659 version, but some parts, for instance the letter of dedication, are based on the 1637 edition. The editions by the widow of Gijsbert de Groot (1704 and 1709), and by the widow of J. van Egmond (s.a.) were also in octavo. ${ }^{61}$ Each follows the version of 1659 with some slight misprints. The octavo editions by the heirs of J. Lescaille contain other misprints; their layer must have been 1699/1716, following the 1659 version. ${ }^{62}$

Another landmark was the abridged edition of 1729 , made by David Ruarus under the influence of changing perceptions of tragedy and theatre and of changing ideas on staging matters of religion. ${ }^{63}$ It was not before 1876 that the 'original' text was returned to. The title of the 1729 edition contains the phrase: 'Now for the first time printed word for word as it is staged on the Amsterdam Theatre' ( $\mathrm{Nu}$ voor de eerste reize van woord tot woord gedrukt, gelijk het op den Amsterdamschen Schouwburg gespeeld wordt). ${ }^{64}$ The 'original' reading text had been reprinted repeatedly, but on stage something completely different was being played. ${ }^{65}$ This shows the intricacy of the relationship between the changing attitude of the literate and the printing history: prints may steer performances and vice versa, and people may or may not give the printed text sacrosanct status.

So Gysbreght van Aemstel underwent several changes, by Vondel himself and by the neoclassical audiences and readerships of the eighteenth century. One would hope for an edition of the 1659 version that takes into account the changes made by Vondel himself at that time and in 1638, as well as the changes in the 1729 edition, so that the author's and the readers' responses can be seen at a glance. ${ }^{66}$

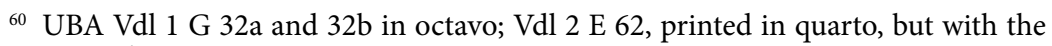
typesetting for an octavo size.

${ }_{61}$ UBA Vdl 1 G 36; Vdl 1 G 39 and 316 F 36 respectively.

${ }^{62}$ Unger, Bibliographie, no. 254; Schuytvlot, Catalogus, no. 530a.

${ }^{63}$ Van der Haven, 'De herziene schouwburgdrukken van 1729'; Albach, Drie eeuwen 'Gysbreght van Aemstel', p. 37 'verthoonige vande superstitien vande paperije als misse en andere ceremonien'; Albach, Drie eeuwen 'Gysbreght van Aemstel', pp. 13 and 20. In an appendix, Markus printed the 1637 text with the changes of 1729 in a second column.

${ }_{64}$ UBA Vdl 2 G 27; Unger, Bibliographie, no. 262.

${ }^{65}$ The text of the preface and the changes can be found on the Internet, in the contribution by Markus, 'De Gysbreght bestaat niet', appendices 1 and 2. It is a pity although understandable - that Markus compared the 1729 edition with the one of 1637 and not with 1659, which had actually been altered.

${ }^{66}$ There is no edition of Gysbreght like The Three-Text Hamlet by Bertram and Kliman, offering a parallel edition of three differing texts of Hamlet.
} 


\section{Vondel's Proofs - Maria Stuart}

Maria Stuart appeared in 1645 with a fictitious printer's address 'In Cologne, at the old printing office' (Te Keulen in doude druckerye). In one year, six editions saw the light of day ${ }^{67}$ Vondel left out his own name and the name of the printer and the publisher because he deemed the subjects too holy to expose them to satire and mockery. Yet the name of the author and the printer soon became known and the magistrates ('Schepenen') of Amsterdam imposed a penalty of 180 guilders on Vondel. ${ }^{68}$ The publisher, who was actually Abraham de Wees, paid the fine.

In 1912 the Vondel-Museum bought a manuscript that was the printer's proof of this play, annotated by Vondel himself. ${ }^{69}$ It shows that, at least in this case, the playwright painstakingly checked this proof. He corrected typesetter's errors, but also altered verses. Thus in lines 791-92 the text reads 'Laet schepes loopen en verslinnen / Wat wil [...]'. This is incomprehensible, but Vondel indicated that the final 's' of 'schepes' should be combined with 'loopen', so that the lines ran 'Laet schepe slopen en verslinnen / Wat wil [...]' (Let anyone wishing to do so scrap ships and devour them). ${ }^{70} \mathrm{He}$ also changed words; on p. 225, for instance, he altered 'secta hominis' (cut off by [the hand of] a man) into 'secta odio' (cut off by hatred) and in line 691 'knotte' (truncated) into 'maaide' (mowed), which corresponds better to the 'scythe' (zeis) that is the instrument for this purpose.

\section{Gebroeders - Notes on a Performance}

In the case of Gebroeders a copy is extant with autograph annotations by Vondel himself. ${ }^{71}$ In it he preserved his memories of a special

${ }^{67}$ Unger, Bibliographie, nos. 431-36; Schuytvlot, Catalogus, nos. 633-43.

${ }^{68}$ Sterck, Oorkonden, p. 221.

${ }^{69}$ Sterck, Oorkonden, pp. 220-34. Now in the University Library of the University of Amsterdam.

${ }^{70}$ Sterck, Oorkonden, p. 224.

${ }^{71}$ Leerintveld, 'Een bijzonder exemplaar van Vondels Gebroeders'; Smits-Veldt, 'De aantekeningen bij Vondels Gebroeders', transcription in WB, 3, pp. 900-02. The copy is in the Royal Library in The Hague, shelf no. $392 \mathrm{H} \mathrm{28}$; facismiles in Geesink and Bossers, Vondel!, p. 89; Albach, Langs kermissen en hoven, p. 48; Van Gemert, Tussen de bedrijven door?, p. 127; Honderd hoogtepunten van de Koninklijke Bibliotheek, p. 127; Oey-de Vita and Geesink, Academie en Schouwburg, p. 228. 


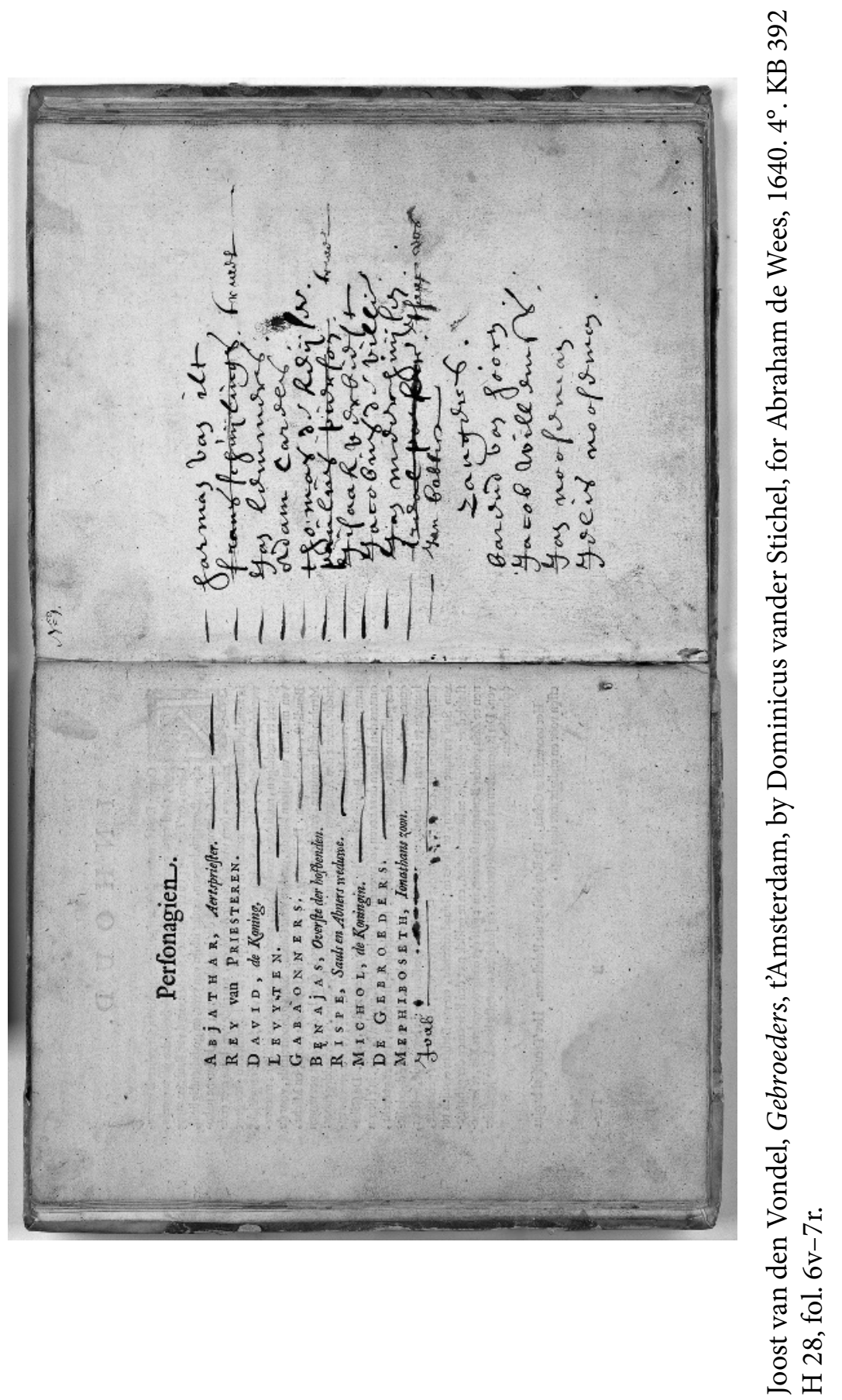


performance for the magistrates of Amsterdam on 20 April $1641 .{ }^{72}$ On an extra leaf bound between B and Bij he noted the actors (fig. p. 503). He also changed the cast. These handwritten changes did not materialise in a printed edition until the 1970s, when Karel Porteman adopted them in his edition. ${ }^{73}$

On a second leaf, inserted between [x] $\mathrm{v}$ and [x2]r Vondel described the props used at the performance, such as the ark and a candle, and the garments of the priests and the high priest. Moreover, he wrote down that musicians played on wind instruments and that the priests sang. For instance, on p. [B4]r, there is a note stating that 'the tableau vivant of the Ark of the Covenant and the candle, and the additional song is spoken by the priests thus' (de vertooning. van de bondskist en kandelaer en de toesang. word aldus van de priesters gesprooken). All this also affected the performance.

Another important change concerned the expansion of the role of general ('veldheer') Joab. His role was enlarged by adding a few clauses from other characters: general Benajas and highpriest Abjathar. The direct cause of this change was perhaps the talent of the seventeen-year old actor Jan Baptist van Fornenberg, whom Vondel provided with the role of Joab. ${ }^{74}$

\section{Different Prints - Adam in Ballingschap}

Adam in ballingschap was published twice in 1664 by the widow of Abraham de Wees. ${ }^{75}$ The two editions are printed by two different printers: the successor of Thomas Fonteyn and Daniel Dakkamude, both in Amsterdam. At first sight, the two editions are identical, but they are made with different letters, contain several variants in spelling and have some differences in wording. They even have different vignettes - one (B) with the printer's motto 'Elk zyn beurt' (Each has his turn), the other one (A) without. To cite a few other instances, in

\footnotetext{
${ }^{72}$ This date was found by Leerintveld, 'Een bijzonder exemplaar van Vondels Gebroeders'.

${ }^{73}$ See Vondel, Gebroeders, ed. Langvik-Johannessen and Porteman, esp. pp. 37-38.

${ }_{74}$ Vondel, Gebroeders, ed. Langvik-Johannessen and Porteman, p. 37; Albach, Langs kermissen en hoven, pp. 44-46. Korsten, Sovereignty as Inviolabity, p. 97, argues that the change was motivated by the content of the conflict.

${ }^{75}$ Unger, Bibliographie, nos. 676 and 677; Schuytvlot, Catalogus, nos. 741 and 742. I will refer to them as 'A' and ' $\mathrm{B}$.' The fingerprint of A is $166404-\mathrm{b}$ A2 \$nae: b2 H3 aele; the fingerprint of $\mathrm{B}$ is 166404 - b1 1 \$nae: b2 H3 rael.
} 
the Title of the dedication A has 'oudemannenhuis' and 'weeshuis', B 'Oude Mannen-huis' and 'Weeshuis'. Although the spelling differs within each copy too, A often spells words ending in an alveolar plosive consonantal sound using a 't' (e.g. 'out', 'tyt' and 'niemant'), whilst $B$ does so using 'dt' (e.g. 'oudt' 'tydt' and 'niemandt'). ${ }^{76} \mathrm{On} \mathrm{p.} \mathrm{Br,} \mathrm{A} \mathrm{has}$ 'Erfrechtveerdigheit', B 'Erfrechtvaerdigheit'. On p. 23, A has 'in de lommer', B the metrically less correct combination 'in lommer. The question subsequently arises as to whether $\mathrm{A}$ is a text emended by the printer or by Vondel himself, with $B$ therefore being the oldest version, or whether $B$ is a rashly made reprint of $A$, with $A$ therefore being the oldest one. In any case, the variants enable us to trace one of them, $B$, as the layer for the subsequent editions of Joannes de Wees, 1698, and Steeve van Esveldt, $1736 .{ }^{77}$ The 1720 edition is more complex, containing variants from both editions. ${ }^{78}$

What is the use of this exercise? I think there are four reasons for doing this. Firstly, something can be said about Vondel, his spelling and his treatment of his texts; secondly, one could look at later editions in order to establish which text was the layer of this edition; and thirdly, it says something about the readers' reception of Vondel's works. The fourth reason is the most fundamental - it shows the fluidity of texts which we think of as a fixed entity, but above all it affects our attitude to the text and opens our eyes to their manifold material forms. A good edition therefore takes these variants into consideration and presents them.

\section{From the Book to the Computer}

In 2003 the Digitale Bibliotheek der Nederlandse Letterkunde (www. dbnl.nl) began to digitise the WB edition of Vondel's works. Now Vondel's texts are available all over the world. This development makes us once more aware of the fact that a text in itself is not sufficient, but needs mediation through materialisation in any form. In other words, we can read the text only by means of a visualisation. The electronic text is an additional form to the printed book. Of course, the monumental material form of the WB series is lost at the dbnl website, but

\footnotetext{
76 P. A2r and p. 3.

77 Unger, Bibliographie, nos 678 and 679; Schuytvlot, Catalogus, nos 743 and 746.

78 Unger, Bibliographie, no. 27a; Schuytvlot, Catalogus, no. 744.
} 
the advantage of being able to consult the text on a computer is tremendous. It renders the text readily searchable for words, citations, etc. And yet the dbnl site has not yet been able to explore the possibilities of digitised texts (the costs would have been too high for the project). At the Huygens Institute for the History of Netherlands in The Hague tools are being developed for further exploration of the opportunities presented by electronic texts. There is the option of presenting several text formats (such as facsimiles, transcriptions, transliterations and annotations) next to each other on the screen..$^{79}$ The users may make their own choices, or even add their own comments, either for their own eyes only or to share their remarks with others. Several scholars can work together on an edition, using information-sharing programs such as $e$-Laborate. But even larger text corpora may be searched and analysed. For instance, style analysis can be carried out, or the dissemination or development of concepts and ideas in Vondel's dramatic oeuvre can be sorted out at a single glance. Although we present our electronic texts - and hypertexts - in forms that look like books, using traditional bookish fonts, they actually differ from the traditional book, as well as offering new opportunities, for old and new philology too.

\section{Coda}

What is new about this story? In classical philology, text editions contain intricate apparatus critici with variant readings and emendations suggested by previous scholars. The same holds for some editions of early modern Latin texts. This has also been done (though presented in a different way) in some editions in the Monumenta Literaria Neerlandica series. So the presentation of variants in itself is not new in philology. But for the works of Vondel, such an exercise has not been carried out in this way. In the WB edition the variants of some texts are listed in appendices, yet are not closely related to the text itself. Thus the variants are relegated to a position of subordination, and the text itself is presented as an ideal one.

As I stated earlier, the aim of classical and modern philology differs; classical text editions pertain to transmission of the text, while in

${ }^{79}$ The electronic text has been called a 'liberation technology' that renders it possible 'to free the writing from the frozen structure of the page', Bolter, Writing Space, p. 21, quoted in Kastan, Shakespeare and the Book, p. 112. 
editions of, shall we say, poets of the 20th century the issue is the genesis of the text. As such, classical philology tries to trace back to the 'original' text, while in many cases modern philology tends to try and pin down the 'final' text that corresponds to the author's 'intention.8 Vondel's editors stood in the tradition of classical philology. Therefore they used the first text authorised by Vondel himself.

I am not arguing a case for the contrary (for editing Vondel's 'final' versions - 'Ausgaben letzter Hand'), nor a case for the same (editing Vondel's first texts). Rather, I favour a combination, a fully fledged place for the variants in line with New Philology and doing justice to the fluidity of the texts or the dynamic process in which they were formed and transmitted, both in prints and performances. In this form, each text should be subjected to its own set of questions. In the case of Gysbreght van Aemstel, Vondel himself changed the text to such an extent that a separate edition of the second version (or a parallel edition) could be expedient, all the more so since the 'Urtext' has already been published several times. For Maria Stuart, the adoption of Vondel's remarks in an apparatus criticus on the page itself may make it perfectly and verifiably clear what he did to the text, and for Gebroeders it could be prudent to present the reader with Vondel's own annotations close to the text itself. And in the case of Adam in ballingschap the variants could be put in an apparatus to make it possible to see the differences between the two versions at a glance.

Of course, not all variants are of the same value, but the material history of the texts and their fluidity should be shown, just as is often done in the restoration of buildings and paintings that do not do away with the several changes in time. The editor should show the inconsistencies, lacunas and the like, rather than reason them away as has been done in twentieth-century preoccupation with a 'monolithic' text in which everything fits in with everything else. Thus the variants, even the ones that at first sight seem to be uninteresting, play a major role, since they affect our perception of early modern texts. The task of the reader will also change - instead of reading a text in which the editor has made the choices for him - to the exclusion of other readings - the scholar using an edition should make his or her own choices, and

\footnotetext{
${ }^{80}$ See (for example) Greg, The Editiorial Problem in Shakespeare, p. x: 'The aim of a critical edtion, should be to present the text, so far as the available evidence permits, in the form in which we may suppose that it would have stood in fair copy, made by the author himself, of the work as he finally intended it.'
} 
reflect on the choices she or he makes. Thus editing texts and reading such editions is not just a game for connoisseurs, it can become a kind of deconstruction and reconstruction. Seen in this way, showing the variants should be part of editing. For variants are parts of the text in their own right, they are the text, and they deserve to be emancipated. 